\title{
Application and effect of addition of popped makhana flour on the properties and qualities of cookies
}

\author{
-SAndeEP KumaR*, InderJeEt Singh, Nitin KumaR ${ }^{1}$ and ChaRAnJiv SingH
}

Department of Food Engineering and Technology, Sant Longowal Institute of Engineering and Technology, Longowal, SANGRUR (PUNJAB) INDIA

Email : sandeepfoodeng@gmail.com

${ }^{1}$ Department of Food Engineering, National Institute of Food Technology Entrepreneurship and Management, SONIPAT (HARYANA) INDIA

*Author for Correspondence

Research chronicle : Received : 18.12.2014; Revised : 01.05.2015; Accepted : 13.05.2015

SUMMARY :

Substitution of wheat flours with non-wheat flours has received considerable attention in recent years due to their positive health benefits. The influence of blending (5-25\%) of popped makhana flour and wheat flour on the physico-chemical, textural and sensory qualities of cookie made from popped makhana-wheat flour blend was investigated. The physico-chemical characteristics of cookies were evaluated in terms of proximate composition and energy value. Physical properties were in terms of cookie diameter, thickness, spread ratio, colour and cookie breaking strength (texture). The cookie sensory qualities were evaluated in terms of texture, mouthfeel, taste, colour and overall acceptability. Increase in the popped makhana flour proportion increased the moisture and protein content of the cookies and resulted in a decrease in the fat, ash content, crude fibre, carbohydrates and energy value of the cookie. Breaking strength of the cookies significantly $(\mathrm{p}<0.05)$ increased whereas cookie diameter and spread ratio significantly decreased with an increase in popped makhana flour proportion. On the other hand, increase in weight and thickness was observed with increase in proportion of popped makhana flour. The colour value in terms of $\mathrm{L}^{*}, \mathrm{a}^{*}$ and $\mathrm{b}^{*}$ also decreased and increase in colour difference was observed. The sensory quality scores of cookie decreased significantly with increase in popped makhana flour proportion. The results of overall acceptability confirmed that replacing of wheat flour with popped makhana flour up to 25 per cent for cookie baking was fairly acceptable by the sensory panelist.

KEY WORDS : Cookies, Makhana, Popped makhana flour

How to cite this paper : Kumar, Sandeep, Singh, Inderjeet, Kumar, Nitin and Singh, Charanjiv (2015). Application and effect of addition of popped makhana flour on the properties and qualities of cookies. Internat. J. Proc. \& Post Harvest Technol., 6 (1) : 80-86. 